\title{
Lean Methodology for Pathology Laboratories: A Case Study from a Public Hospital
}

\author{
Fatih DURUR 1 , Yasemin AKBULUT
}

Department of Healthcare Management, Ankara University, Faculty of Health Sciences ANKARA, TURKEY

\begin{abstract}
Objective: The increase in the financial imposition of laboratories together with developing technology and evidence-based medicine applications increased the importance of quality and efficiency studies in laboratories. The aim of the study is to examine the processes of pathology laboratory, determine the causes of waste and select lean management techniques to eliminate the causes of waste.

Material and Method: A five-phase plan was used for the application of lean management in the pathology laboratory. After a comprehensive literature review, these phases were determined as follows; the support of the senior management, observation, training of employees, drawing of value stream maps and creation of value stream plan. Gastric biopsy process was selected as product/service family when value stream maps were generated. In addition, fishbone diagram and Pareto analysis were used to determine the causes of waste.

Results: In the current state, $73.6 \%$ of the time spent on a gastric biopsy sample in the pathology laboratory was wasted. The most common causes of waste were identified as problems with cleaning, equipment supply problems, lack of clinical information, equipment malfunction and errors. A value stream plan was developed with lean techniques to eliminate the causes of these wastes. In the pathology laboratory, a $4.6 \%$ improvement will be achieved with the achievement of the future stated target.

Conclusion: A model for lean management techniques in a developing country that will enable the pathology laboratories to work more efficiently and with improved quality has been developed in this study.
\end{abstract}

Key Words: Cost, Efficiency, Lean methodology, Management, Pathology laboratories, Waste

\section{INTRODUCTION}

Lean management is a method recommended for reducing waiting times, waste and costs in health care facilities to improve quality and efficiency $(1,2)$. In an environment where health expenditures are constantly increasing and resources are limited, health institutions should reduce their costs and increase their efficiency in order to survive. In recent years, in order to reduce waste, improve processes and increase efficiency, the number of health institutions applying lean management has increased. In this way, they aim not only to compete with other institutions but also to increase and stabilize their market share (3-5).

Although lean management studies in the public health sector are more disadvantaged than the private sector in terms of budget, hierarchical structure and sustainability, successful results can be obtained (6-8). Lean management in the public sector is used to improve clinical processes, patient care, treatment practices, operation and laboratory processes, and imaging services (9-17). However, since laboratories are the units that are most similar to a

(Turk Patoloji Derg 2019, 35:228-236)

Received : 02.02.2019 Accepted : 08.05.2019 processing department within health care institutions, they are widely accepted in lean management practices and are generally chosen as the starting point in lean management practice $(3,5)$. In addition, advances in diagnosis and treatment, evidence-based medicine practices and technological changes, as well as the increased financial restrictions imposed on laboratories, have increased the interest in quality and productivity in laboratories $(18,19)$. On the other hand, the number of lean management studies conducted in pathology laboratories is very limited and generally include examples from developed countries (20-24).

This study was carried out in the pathology laboratory of a public hospital in Ankara, Turkey. The aim of the study is to examine the processes of pathology laboratory, determine the causes of waste and select lean management techniques to eliminate the causes of waste. With this leading work, a model is proposed in lean management techniques in a developing country that will enable the pathology laboratories to work more efficiently and with improved quality.

Correspondence: Fatih DURUR

Department of Healthcare Management,

Ankara University, Faculty of Health Sciences, ANKARA, TURKEY

E-mail: durur@ankara.edu.tr Phone: +90 3123191450 


\section{MATERIAL and METHOD}

\section{Work Environment}

This study was carried out at Diskapi Yildirim Beyazit Training and Research Hospital with 770 bed capacity in Ankara, Turkey. The hospital with 770 bed capacity, 68 intensive care beds, 29 operating rooms, intensive care services, pathology, microbiology, biochemistry, genetics and tissue typing laboratories and emergency services with a total of 174 main branches and sub-branch clinics. In hospital pathology laboratory, histopathology and cytopathology services are provided. Immunohistochemical staining and histochemical staining can also be performed. There were 43 employees in the pathology laboratory at the time of the study. The laboratory, which has more than 30000 materials a year, serves 5 days a week between 08.0017.00 hours (25).

\section{Data Collection}

This study was carried out between September 2017 and May 2018. Data on this current state of the pathology laboratory were obtained from the hospital statistical unit and pathology laboratory. In addition, participatory observation and unstructured interview method were used to collect the data of lean methodology and semistructured observation forms were used to record the findings obtained during the observation.

\section{Lean Methodology}

Lean management is based on five basic principles: value, value stream, flow, pull and perfection (1). Application phases and techniques used differ according to the work spaces. As a result of literature review in this study $(1,2,3,5,11,26,27)$ an application plan consisting of five phases was created. These phases were determined as taking the support of the senior management, observation, training of the employees, drawing up the value stream mapping and creating the value stream plan.

\section{Phase 1: Support of the Senior Management}

Senior management support for lean management practices is the first and the most important element $(1,3,28)$. The most important factor in the selection of the hospital is that the hospital staff members had been trained in lean management in health institutions. As a result of face-toface meetings with senior management, the management participation for the study conducted was guaranteed. They were eager for lean practices and provided legal permission for the study.

\section{Phase 2: Observation}

In the second stage of the study, one month (November 2017) with intermittent observation method 14 observations were performed in the pathology laboratory. During observations, semi-structured observation forms were utilized to record the data to be used in other stages of the study. In order to strengthen the observation method, it is recommended to use together with the interview method $(29,30)$. For this reason, information about pathology laboratory processes was obtained from the employees with unstructured interview method.

\section{Phase 3: Training of Employees}

As employee participation is very important in lean management applications $(31,32)$, employees are required to know the lean management terms and the lean management tools. For this purpose, training programs covering lean management concepts and definitions, techniques used in lean management practices and examples of lean management in health institutions were organized. The training programs were carried out by researchers in two sessions of 50 minutes to physicians and other laboratory staff. At the same time, the employees and researchers exchanged ideas for the next stages of the study and their questions were answered.

\section{Phase 4: Value Stream Mapping}

It is aimed to visualize the process steps with value stream mapping, to determine the causes of waste in the process and to create plans for the elimination of these matters (33). In this way, process spaces that work in accordance with lean management principles can be revealed. The product/ service family selection, creating the current state map and setting the future state map were followed in the creation of the value stream mapping in the pathology laboratory in this study (15).

\section{Product/Service Family Selection}

It will be quite complicated to show the entire process and stream of information in a business area on a single map (33). For this reason, firstly a product/service family selection should be made in value stream mapping. In this study, "gastric biopsy" samples were selected as product/ service family considering the number of samples and units in which they were processed in the laboratory. In this way, it was possible to examine all processes in the pathology laboratory. 


\section{Current State Map}

The next step after selecting the product/service family is the creation of the current state map. The data used in the preparation of the current state map were obtained from the records of the pathology laboratory as well as observations and interviews. For the calculation of the periods with added value and waiting time (did not add value), the samples were monitored during the process and measurements were made with the timepiece. In this study, "gastric biopsy" samples consisting of 44 models were selected and recorded as product/service family for recording the current state map.

In this current state, there are 11 pathologist, 7 assistant pathologist, 15 laboratory technicians, 7 medical secretaries, 2 servants and 1 hospital cleaning staff in the pathology laboratory. The laboratory serves every weekday between 08.00-17.00 hours. During this period when the study was carried out, a total of 25488 samples, 20274 biopsies and 5214 cytology were examined in the pathology laboratory. The results in the biopsy period in the pathology laboratory were 3.99 working days; the period of cytology results was 2.57 working days. When the number of inappropriate samples was examined in the pathology laboratory; it was observed that 90 samples were rejected between January, 2017 and May, 2018. When the reasons for rejection were examined, pre-diagnosis/clinical information deficiency $(n=25)$, inappropriate transfer $(n=17)$, lack of doctor's cachet $(n=15)$, irregular entry $(n=10)$ and other reasons $(n=23)$ were determined.

The basic processes in pathology laboratory value stream include pathology request, sample acceptance, macroscopy, tissue surveillance, blocking, sectioning, incubator, staining/coverslipping, immunohistochemistry/ histochemistry, microscopic examination, reporting, report control and archive steps. In the pathology laboratory, it was observed that there is a long waiting period between the stages of macroscopy/tissue surveillance, microscopic examination/reporting and report control/conclusion. In the pathology laboratory, the current state mapping for the gastric biopsy (Figure 1) was examined, time of stream in the pathology laboratory was 74 hours 09 minutes, waiting period was 54 hours 37 minutes, and a value added period was 19 hours 32 minutes. Currently, $73.6 \%$ of the time spent in the pathology laboratory for gastric biopsy samples did not add value.

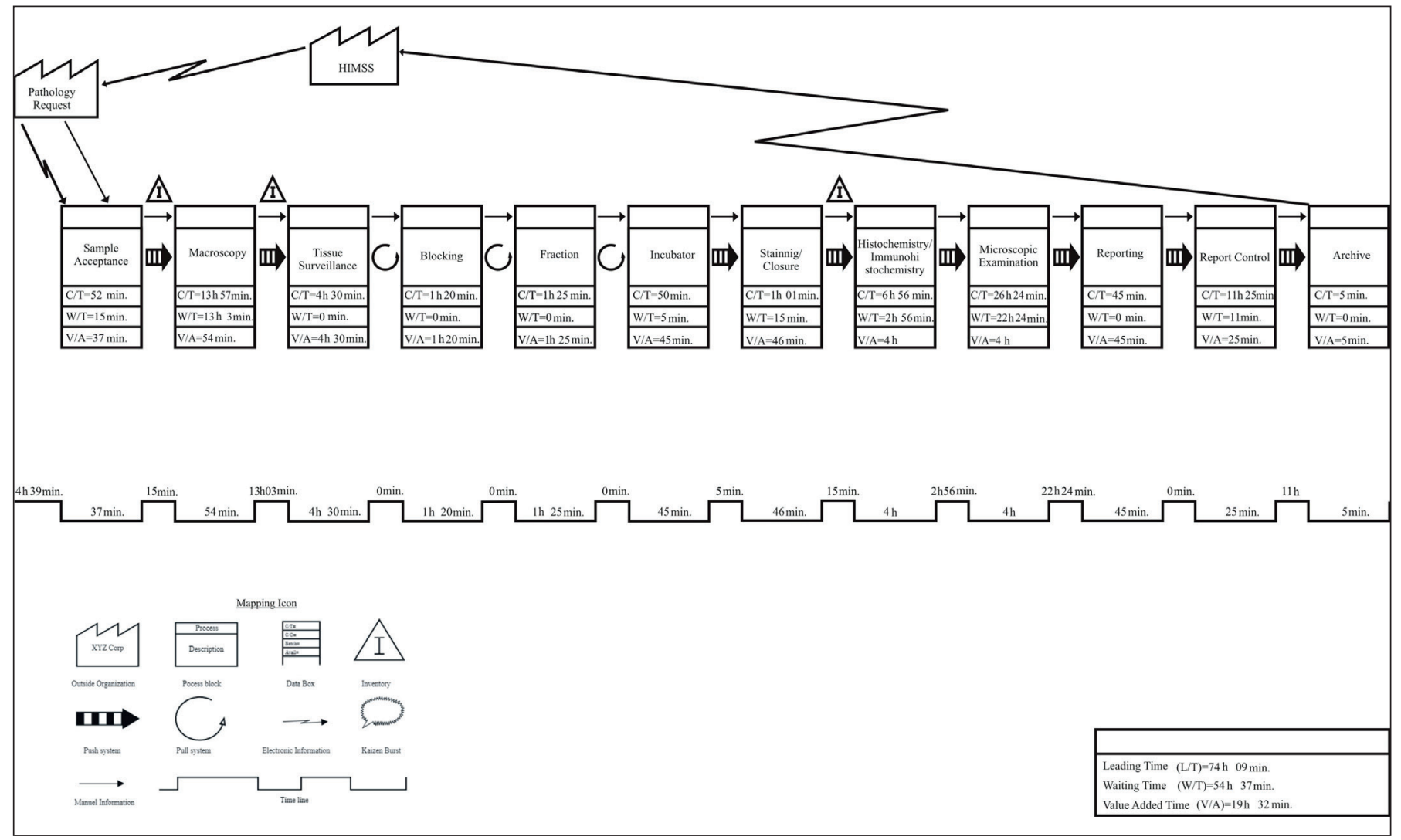

Figure 1: Current state map. 
In the pathology laboratory, the wastage reasons determined by the current state mapping are listed below:

- It has been determined that appropriate transport containers were not used for transfer of pathology samples to the laboratory. For transfer of samples to the laboratory, carrying cases that hold materials at a certain temperature should be used. Samples which are not carried under appropriate conditions may affect the pathology result. In addition, rejection of samples that were not carried under appropriate conditions causes a waste of time and cost.

- "Lack of clinical information" sent in request forms causes waste of time. The lack of clinical information was among the top reasons for sample rejection. The lack of clinical information affects pathologists' diagnosis times and causes wasted time and error.

- There was no warning system for infected material (HIV, Hepatitis) on samples sent to the pathology laboratory. This can be a waste of error and also pose a threat to occupational safety.

- Samples taken to the sample acceptance and recording unit were both electronically recorded to the hospital information management system (HIMS) and a pathology registry was kept manually. Post-recording samples were very difficult to follow in laboratory. This situation causes waste of time and error. In addition, the tracking number of the materials coming to the laboratory was given manually by the secretary. This may cause possible waste of error.

- During the report creation phase, a secretary at the macroscopy unit wrote a report to the assistant or senior physician. This causes waste of error and time.

- Laboratory unit is the area where blocking, sectioning, incubator and staining/cover slipping operations are performed. In the pathology laboratory there was an employee responsible for cleaning and supply of materials. Lack of these personnel in this area causes problems in cleaning and supplying materials.

- In the laboratory, the outcome report was recorded by the secretary after being registered to HIMS, and two outputs (for patient and archive) were submitted to the approval of the pathologist. If the report required correction, the process was repeated. This causes unnecessary material use and unnecessary act of the secretary. In addition, the time elapses and there is dissipation of time.
- In the laboratory, there was no archiving area for the samples coming with consultation. This can cause possible waste of error, making it difficult to find materials and also wastes time.

\section{Future State Map}

The next step after the current state map was the creation of a future state map. The transportation of the samples to the laboratory with the future state map, sample acceptance, macroscopy, reporting and archive sections were determined as kaizen point. In addition, the sample acceptance unit was selected for $5 \mathrm{~S}$ application in the laboratory area including work standardization and blocking, sectioning, incubator, staining and cover slipping (Figure 2). Although some processes in the pathology laboratory did not create value, they must be maintained in the current state. For example, samples wait for 13 hours 03 minutes for tissue surveillance after macroscopy and this causes time wasting. However, an improvement to eliminate this waste will result in the accumulation of staining and microscopic examination units. Therefore, in order to maintain the current state, this waiting is currently required and cannot be eliminated.

In the preanalytical process with future state map, it is aimed to eliminate error and time with kaizen applications in macroscopy units and sample acceptance; waste and unnecessary movement wastes with the $5 \mathrm{~S}$ application to be made in the laboratory area. With kaizen practices after the reporting at the report control phase the time, cost and movement wastage will be prevented. In addition, continuous stream can be achieved with the principle of pulling between the report and the report control, thus eliminating the waiting period of 11 hours. In this case, the stream time will be 63 hours 09 minutes, the waiting time will be 43 hours 37 minutes, and the value added time will be 19 hours 32 minutes. The rate of waiting time will be reduced from $73.6 \%$ to $69 \%$ and there will be an improvement of $4.6 \%$.

\section{Phase 5: Value Stream Plan}

A value stream plan was prepared in order to achieve the goals set in the future state map. In this study, the fishbone diagram and Pareto analysis were used to develop lean management's principle of respect for people and $(3,34)$ and to increase employee participation in the value stream plan. The causes of wastage as a result of the value stream mapping, observations and meetings were visualized by the fishbone diagram as a result of brain storming with employees of pathology laboratory (Figure 3). 
Causes of wastage as a result of fishbone diagram were determined as unnecessary procedures, lack of information system, equipment malfunctions, equipment supply problems, errors, lack of clinical information, cleaning problems and transportation problems. These causes of waste in the pathology laboratory were collected under the headings of method, equipment, people and other causes. After the creation of the fishbone diagram, Pareto analysis was carried out to select the most important reasons. A form determined by the fishbone diagram was created for the Pareto analysis, and the employees working at the pathology laboratory were asked how often these kinds of waste were encountered. In order to make the necessary calculations for Pareto analysis, the results were rated as rarely $=1$, sometimes $=2$, generally $=3$, and frequent $=4$. Thirty-five of the pathology laboratory employees volunteered to participate in the study. In the first stage, the data were classified, and the cumulative points and

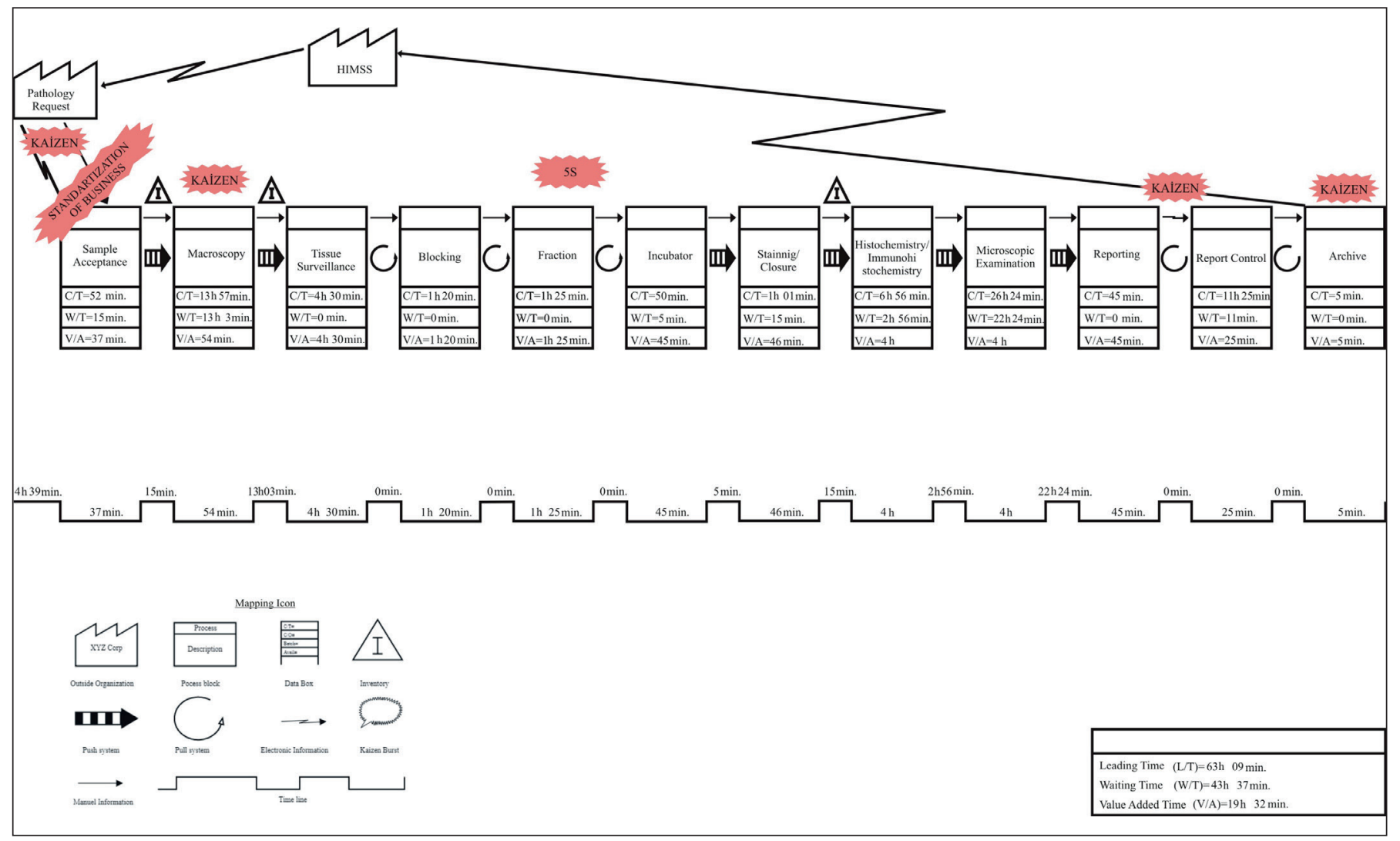

Figure 2: Future state map.

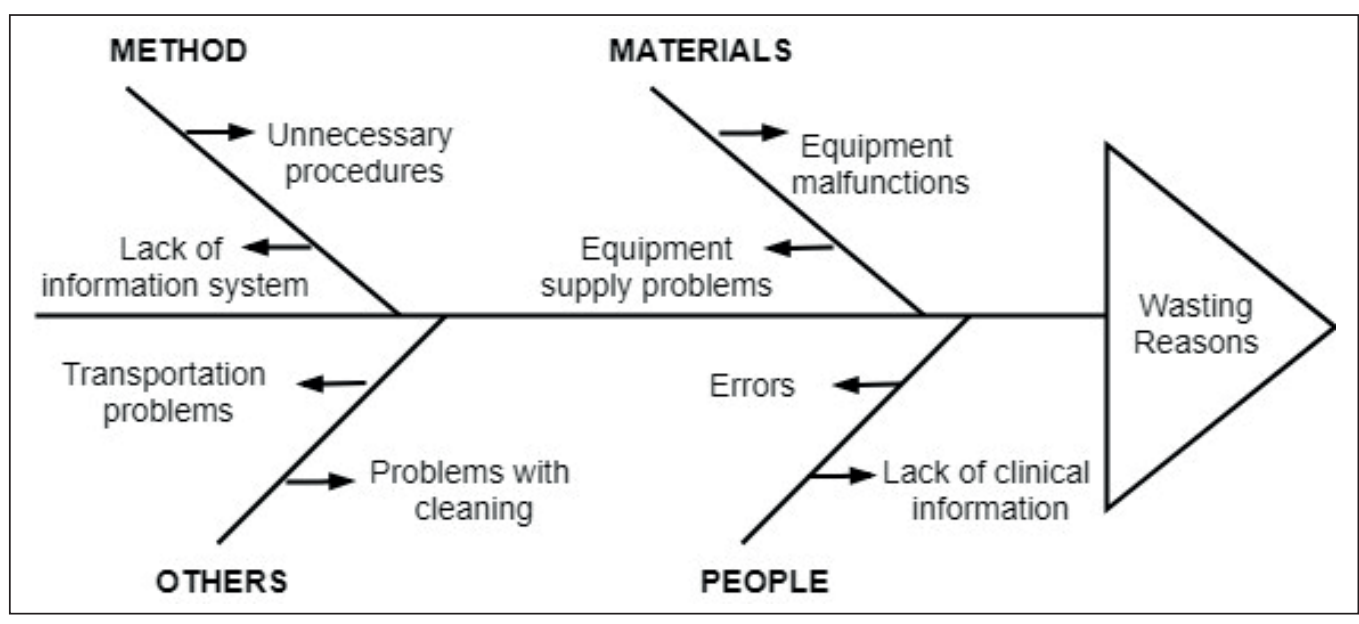

Figure 3: Fishbone diagram. 
percentages were calculated. Cleaning problems were the most common waste with 88 points; the problems encountered in transportation were determined as the least commonly encountered waste with 51 points. A Pareto analysis chart was created to visualize the cumulative scores and percentages calculated in the second stage to apply the 20/80 rule (35) and to determine the causes of waste to be given priority (Figure 4 ).

As a result of Pareto analysis, problems which were below $80 \%$ were selected. These were problems that related to cleaning, problems in supplying material, lack of clinical information, machine failures and errors and thus determined as priority headings. Unnecessary procedures, lack of information systems and problems in transportation were excluded.

Wastage points determined by the fishbone diagram and value stream maps were prioritized by Pareto analysis. After this stage, a value stream plan was established in order to reach the targets in the future state map. The value stream consisted of the determined causes of waste, waste types, the lean techniques to be used and solution offers (Table I).

\section{RESULTS}

In the study, value stream maps, current state of the pathology laboratory and wastage reasons were determined. Accordingly, the duration of stream in the pathology laboratory for a sample of gastric biopsy was determined as 74 hours 09 minutes; waiting period was 54 hours 37 minutes and value added duration was 19 hours 32 minutes. In the current state, $73.6 \%$ of the time spent in the pathology laboratory for gastric biopsy samples has no added value. With the future status map and value stream plan, it was calculated that the stream, material and unnecessary movement wastes could be eliminated, thus, the stream time could be reduced to 63 minutes 09 minutes, waiting period is 43 hours 37 minutes and value added duration is 19 hours 32 minutes. In this case, the rate of duration that does not create added value will be reduced from $73.6 \%$ to $69 \%$ and there will be an improvement as of $4.6 \%$. In order to reach the targets, set in the future status map and to increase employee participation, a value stream plan was created by using fishbone and Pareto analysis. The value stream plan and the wastage reasons defined in the pathology laboratory were classified as wastes of time, error, movement and material and were arranged according to the result of Pareto analysis. Kaizen, business standardization, 5S and visual management were chosen from lean management techniques and solutions were proposed to eliminate the causes of waste.

\section{DISCUSSION}

In this study, the steps of lean management practices performed in a public hospital pathology laboratory are presented. A process analysis based on a lean methodology was performed for the first time in a public hospital pathology laboratory in Turkey. At the end of the study, it was calculated that the waiting period which was 54 hours 37 minutes can be reduced to 43 hours 37 minutes and an improvement of $4.6 \%$ can be achieved. In this way, the number of samples examined can be increased. These results are supported when the literature is reviewed.

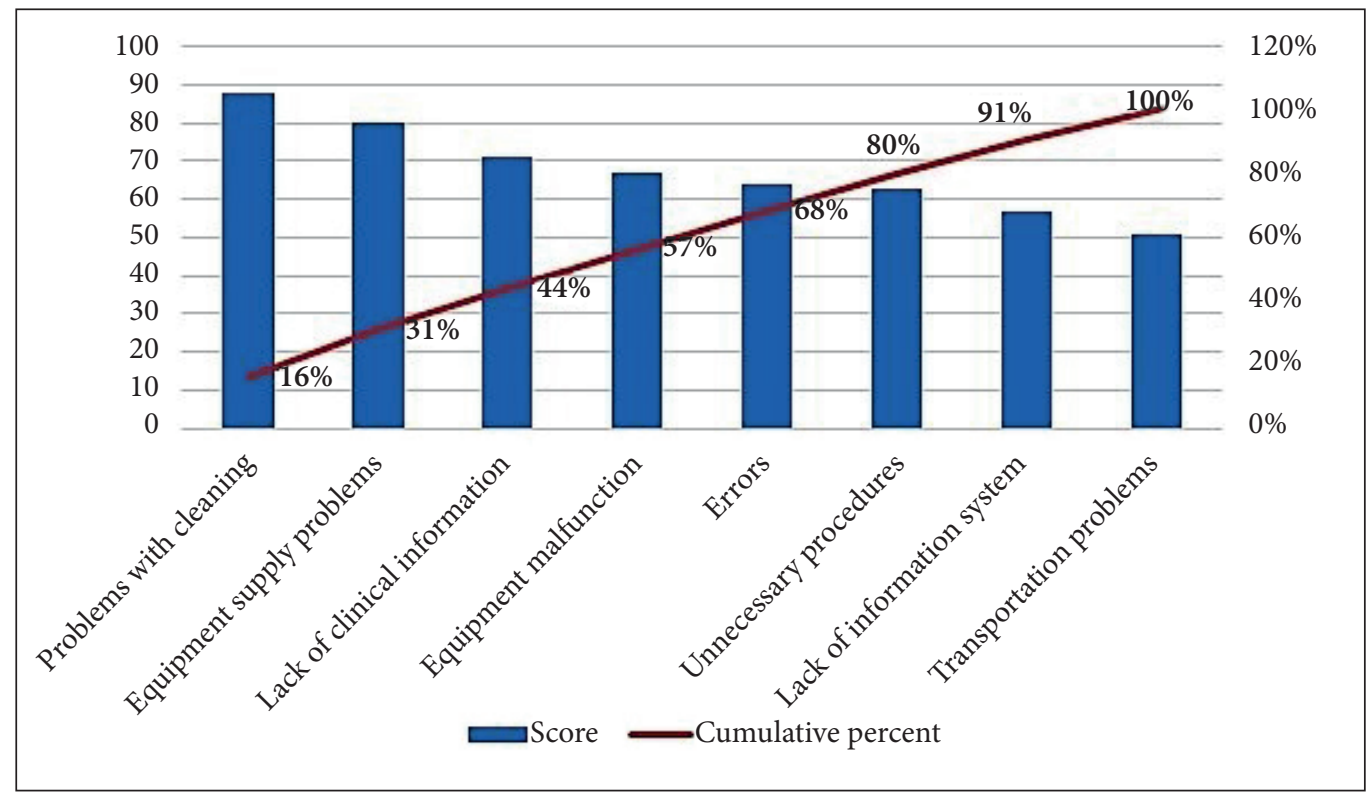

Figure 4: Pareto analysis. 
Table I: Value stream plan.

\begin{tabular}{lccc}
\hline Reason of Wastage & Type of Wastage & Lean Technique & Solution Offer \\
\hline $\begin{array}{l}\text { 1. Cleaning Problems } \\
\begin{array}{l}\text { 2. The lack of archiving space for } \\
\text { consultation samples }\end{array}\end{array}$ & Time, Error & Kaizen & $\begin{array}{c}\text { Ensuring cleaning and organization with } \\
\text { the 5S technique }\end{array}$ \\
\hline $\begin{array}{l}\text { 3. Lack of clinical information in } \\
\text { the pathology request forms }\end{array}$ & Time, Error & $\begin{array}{c}\text { Standardization of } \\
\text { business } \\
\text { consultation samples }\end{array}$ & $\begin{array}{c}\text { Formation of control forms or failure } \\
\text { of the system without entering clinical } \\
\text { information }\end{array}$ \\
\hline $\begin{array}{l}\text { 4. No warning system for } \\
\text { infected material (HIV, hepatitis) }\end{array}$ & Error & $\begin{array}{c}\text { Visual management, } \\
\text { kaizen }\end{array}$ & $\begin{array}{c}\text { Warning signaling via information } \\
\text { management system }\end{array}$ \\
\hline $\begin{array}{l}\text { 5. Result reporting system } \\
\text { 6. Macroscopy report writing }\end{array}$ & Movement, Time & Kaizen & $\begin{array}{c}\text { Electronic delivery of results to physicians } \\
\text { and e-signature }\end{array}$ \\
\hline $\begin{array}{l}\text { 7. Specifying the sample } \\
\text { surveillance number by secretary }\end{array}$ & Time, Error & $\begin{array}{c}\text { Standardization of } \\
\text { business, kaizen }\end{array}$ & $\begin{array}{c}\text { Use of dictation system or standard } \\
\text { macroscopy report templates }\end{array}$ \\
\hline $\begin{array}{l}\text { 8. Sample recording and } \\
\text { surveillance problem }\end{array}$ & Time, Error & Kaizen & Kaizen \\
$\begin{array}{l}\text { 9. Use of appropriate sample } \\
\text { transport materials for transport } \\
\text { of samples to the pathology }\end{array}$ & Error, Time & Kaizen & Barmation system \\
\hline
\end{tabular}

As a result of the lean application of the histopathology department of an anatomical pathology laboratory, the total cycle time decreased from 9.7 hours to 9 hours and the number of samples examined increased from 3439 to 4074 (21). Another study conducted in the pathology laboratory found that, the total time spent by the sample in the system has been reduced from 507 minutes to 238 minutes, while the process that did not add value has been reduced from 358 minutes to 89 minutes (23). In the study carried out in South Dokota, the total cycle time was reduced by $67 \%$ and the number of samples examined increased (37). As a result of the study conducted in a pathology laboratory in an oncology hospital in Brazil, the reporting time were reduced (38). In another study conducted in Canada, the rate of autopsy reports given within 90 days was increased from $37 \%$ to $74 \%$ (39). In addition, the total cycle times and the increase in the number of examined samples were found in the studies conducted in the central laboratories of different hospitals $(11,19,36)$.

Also it was determined in this study that the value stream plan, error and movement wastes in the pathology laboratory can be eliminated. In the pathology laboratory of Dokuz Eylul University Hospital, a study was performed by using various lean instruments to increase productivity.
As a result of the study, the total number of errors were reduced from 110 to 64 and the number of mislabeling errors were reduced from 30 to 15 (24). In the study conducted in a pathology laboratory of a hospital in Detroit, the error rate was reduced by 55\% (20). Another study conducted in Australia eliminated 187 kilometers unnecessary walking per year (22). In the pathology laboratory of the University of Michigan Hospital, the lean applications performed during the Pap test process resulted in an approximately $50 \%$ reduction in the number of errors while in another study conducted in the USA, near-miss events (events, actions or processes expected to be severely damaged if not corrected before reaching the patient) were reduced and contributed to patient safety $(40,41)$. Business processes have been redesigned with lean management applications made in a pathology laboratory in Cleveland and unnecessary movement and time wastes have been prevented (42).

In conclusion, lean management philosophy takes a long time to adopt. Presenting the results of the first phase of a large project is the limitation of the study. The effects of the results obtained with the application of the lean techniques determined in the value stream plan as a result of the study on the costs, results waiting time and error rates can be 
examined in other studies. In addition, the methodology developed to carry out the study can be an example to lean management studies in medical laboratories. In it is important to note that in order to achieve success in lean methodology, the key elements are: the continuous training of employees and their participation in the process. Furthermore, the introduction of the application primarily in a part of the laboratory and then disseminating it to the pre-analytical and post-analytic processes can lead to the creation of a lean management culture.

\section{FUNDING}

This study was supported by the Ankara University Scientific Research Projects Coordinatorship.

\section{ACKNOWLEDGEMENT}

The authors thank İlhan AYDIN, M.D. and all pathology department staff for their contributions.

\section{REFERENCES}

1. Womack JP, Jones DT. Lean Solutions. New York: Free Press; 2015.

2. Barnas K, Adams E. Beyond Heroes: A Lean Management System for Healthcare. Wisconsin: ThedaCareCenter; 2014.

3. Graban M. Lean Hospitals: Improving Quality, Patient Safety and Employee Engagement. 2nd. ed. Boca Raton: CRC Press; 2011.

4. Radnor ZJ, Holweg M, Waring J. Lean in healthcare: The unfilled promise? Soc Sci Med. 2012; 74: 364-71.

5. Protzman C, Kerpchar J, Mayzell G. Leveraging Lean in Medical Laboratories: Creating a Cost Effective, Standardized, High Quality, Patient-Focused Operation. Boca Raton: CRC Press; 2015.

6. Lodge A, Bamford D. New development: Using lean techniques to reduce radiology waiting times. Public Money \& Management. 2008; 28:49-52.

7. Leggat SG, Stanton P, Bamber GJ, Bartram T, Gough R, Ballardie $\mathrm{R}$, Germann K, Sohal A. 4P recommendations for implementing change, from research in hospitals. Public Money\&Management. 2018; 38:45-50.

8. Fournier PL, Jobin MH. Understanding before implementing: The context of Lean in public healthcare organizations. Public Money\&Management. 2018; 38:37-44.

9. Ben-Tovim D, Bassham JE, Bolch D, Martin MA, Dougherty M, Szwarcbord M. Lean thinking across a hospital: Redesigning care at the Flinders Medical Centre. Aust Health Rev. 2007; 31:10-5.

10. Dickson EW, Anguelov Z, Vetterick D, Eller A, Singh S. Use of lean in the emergency department: A case series of 4 hospitals. Ann Emerg Med. 2009; 54:504-10.

11. Rutledge J, $\mathrm{Xu} \mathrm{M}$, Simpson J. Application of the Toyota production system improves core laboratory operations. Am J Clin Pathol. 2010; 133:24-31.
12. John S, Toussaint MD, Berry LL. The promise of lean in health care. Mayo Clin Proc. 2013; 88:74-82.

13. Chiarini A. Waste savings in patient transportation inside large hospitals using lean thinking tools and logistic solutions. Leadersh Health Serv. 2013; 26:356-67.

14. Farrokhi FR, Gunther M, Williams B, Blackmore CC. Application of lean methodology for improved quality and efficiency in operating room instrument availability. J Healthc Qual. 2015; 37:277-86.

15. Henrique DB, Rentes AF, Filho MG, Esposto KF. A new value stream mapping approach for healthcare environments. Production Planning\&Control. 2016; 27:24-48.

16. Haron SHA, Ramlan R. Patient process flow improvement: Value stream mapping. Journal of Management Research. 2015; 7:495505.

17. Matos IA, Alves AC, Tereso AP. Lean principles in an operating room environment: An action research study. Journal of Health Management. 2016; 18:239-57.

18. Yörükoglu K, Usubütün A, Doğan Ö, Önal B, Aydın Ö. Türkiye'de Patoloji Laboratuvarında Kalite Kontrol. Turk Patoloji Derg. 2009; 25:29-37.

19. Lou AH, Elnenaei MO, Sadek I, Thompson S, Crocker BD, Nassar BA. Multiple pre- and post-analytical lean approaches to improvement of the laboratory turnaround time in a large core laboratory. Clin Biochem. 2017; 50:864-9.

20. Zarbo RJ, D'angelo R. Effective reduction of process defects and waste in surgical pathology. Am J Clin Pathol. 2007; 128:1015-22.

21. Raab SS, Grzubicki DM, Condel JL, Stewart WR, Turcsanyi BD, Mahood LK, Becich MJ. Effect of lean method implementation in the histopathology section of an anatomical pathology laboratory. J Clin Pathol. 2008; 61:1193-9.

22. Hayes KJ, Reed N, Fitzgerald A, Watt V. Applying lean flows in pathology laboratory remodelling. J Health Organ Manag. 2014; 28:229-46

23. Sugianto JZ, Stewart B, Ambruzs JM, Arista A, Park JY, Yokoyama SC, Luu HS. Appliying the principles of lean production to gastrointestinal biopsy handling: From the factory floor to the anatomic pathology laboratory. Lab Medicine. 2015; 46:259-64.

24. Yörükoglu K, Özer E, Alptekin B, Öcal C. Improving histopathology laboratory productivity: Process consultancy and A3 problem solving. Turk Patoloji Derg. 2017; 33:47-57.

25. Hospital Statistics (2018). Dışkapı Hastanesi Tanıtım, Available from: http://www.diskapieah.gov.tr/diskapil/diskapi-hastanesi/. Accessed at April 2018.

26. Buesa RJ. Adapting lean to histology laboratories. Ann Diag Pathol. 2009; 13:322-33.

27. Wojtys EM, Schley L, Overgaard KA, Agbabian J. Applying lean techniques to improve the patient scheduling process. J Healthc Qual. 2009; 31:10-6.

28. Alefari $\mathrm{M}$, Salonitis $\mathrm{K}, \mathrm{Xu} \mathrm{Y}$. The role of leadership in implementing lean manufacturing. Procedia CIRP. 2017; 63:75661.

29. Bas T, Akturan U. Nitel Araştırma Yöntemleri: NVivo 7.0 ile Nitel Veri Analizi. Ankara: Seçkin Yayıncılık; 2008. 
30. Beaudry JS, Miller L. Research Literacy: A Primer For Understanding and Using Research. New York: Guildford Press; 2016.

31. Drotz E, Poksinska B. Lean in healthcare from employees perspectives. J Health Organ Manag. 2014; 28:177-95.

32. Lindskog P, Hemphala J, Eklund J, Eriksson A. Lean in healthcare: Engagement in development, job satisfaction or exhaustion? J Hosp Adm. 2016; 5:91-105.

33. Rother M, Shook J. Learning to See: Value Stream Mapping to Add Value and Eliminate Muda. Brookline: The Lean Enterprise Institute; 1999.

34. Clark DM, Silvester K, Knowles S. Lean management systems: Creating a culture of continuous quality improvement. J Clin Pathol. 2013; 66:638-43.

35. Sarp N. Toplam Kalite Yönetimi Uygulamaları. Ankara: Siyasal Kitabevi; 2014.

36. Persoon TJ, Zaleski S, Frerıchs J. Improving preanalytic processes using the principles of lean production. Am J Clin Pathol. 2006; 125:16-25.
37. Serrano L, Hegge P, Sato B, Richmond B, Stahnke L. Using lean principles to improve quality, patient safety and workflow in histology and anatomic pathology. Adv Anat Pathol. 2010; 17: 215-21.

38. Quetz JS, Dantas IF, Hirth CG, Brasil CG, Juacaba SF. Preliminary results of Lean method implementation in a pathology lab from Northeastern Brazil. J Bras Patol Med Lab. 2015; 51:33-8.

39. Cromwell S, Chiasson DA, Cassidy D, Somers GR. Improving autopsy report turnaround times by implementing lean management principles. Pediatr Dev Pathol. 2018; 21: 41-7.

40. Michael CW, Naik K, McVicker M. Value stream mapping of the Pap test processing procedure: A lean approach to improve quality and efficiency. Am J Pathol. 2013; 139: 574-83.

41. Smith ML, Wilkerson T, Grzybicki DM, Raab SS. The effect of a lean quality improvement implementation program on surgical pathology program specimen accessioning and gross preparation error frequency. Am J Pathol. 2012; 138: 367-73.

42. Yerian LM, Seestadt JA, Gomez ER, Marchant KK. A collaborative approach to lean laboratory workstation design reduces wasted technologist travel. Am J Pathol. 2012; 138: 273-80. 